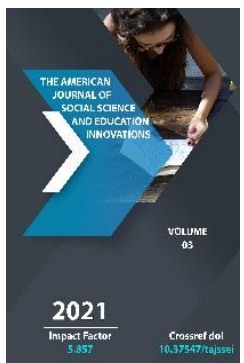

\title{
Pedagogical Approach To The Preparation The Children Of The Orphanage For Family Life
}

\author{
Xaydarova Shaxlo Narzullaevna \\ Navoi State Pedagogical Institute, Navoi, Uzbekistan
}

Copyright: Original

content from this work may be used under the

terms of the creative

commons attributes

4.0 licence.

\section{ABSTRACT}

The article emphasizes that the social adaptation of orphans and their preparation for family life is one of the most important tasks of the state and society. Today, much attention is paid to the selfrealization of the younger generation, its harmonious development in all respects. The fact that a nation perceives itself as a result of such created conditions gives it confidence and gives it a reason to look to a promising future.

\section{KEYWORDS}

Orphanages, homeless baby, social protection, family life, legal representative, qualimetric analysis.

\section{INTRODUCTION}

As you know, the role of orphanages in human development is limitless. But no orphanage can replace a family. Some children are forced to grow up in orphanages by the will of fate or because of people unworthy of the name of some parents. Orphanhood is a divine destiny that is prescribed to a person. In fact, you cannot run away from fate, and such a fate brings an orphan to an orphanage. For the first time, orphanages appeared in 1918 as 
orphanages. Due to the fact that during this period many families were destroyed for various reasons, orphanages were created in order to feed orphans and neglected children and raise them as people devoted to society. During World War II, special orphanages were opened, in which children of different nationalities from Ukraine, Belarus, Lithuania, Latvia, Estonia, Moscow, Leningrad and other cities were brought up. Over the years of independence, on the initiative of the First President of the Republic of Uzbekistan I.A. Karimov, orphanages were named "House of Kindness". The purpose of orphanages is to protect the rights and interests of orphans and children left without parental care, to ensure their healthy development, to realize their rights with special assistance and care from the state. In recent years, large-scale work has been carried out in our country to prevent social orphanhood, to promote a responsible approach to building a healthy family among the population and youth, and to form a spiritual and moral attitude towards family values. Many laws of our state aimed at educating the younger generation are able to fully protect the vulnerable layers of our society.

\section{MATERIALS AND METHODS}

The adoption today of the relevant regulatory legal acts in this area, such as the Law of the Republic of Uzbekistan "On State Youth Policy" adopted on September 14, 2016, The Law of the Republic of Uzbekistan "On guarantees of the rights of the child", Decree of the President of the Republic of Uzbekistan dated February 7, 2017 "On the strategy for the further development of the Republic of Uzbekistan", Resolution of the President of the Republic of Uzbekistan dated February 11, 2019 "On additional measures to strengthen social protection of orphans and children deprived of parental care", Resolution of the Cabinet of Ministers of the Republic of Uzbekistan "On the choice of alternative forms of accommodation for orphans and children deprived of parental care, strengthening the institution of the family and measures to improve the system for preventing social orphanhood" dated September 30, 2019, The Law of the Republic of Uzbekistan "On Education" dated September 23, 2020, Article 54 "Education and full provision of orphans and children deprived of parents or other legal representatives" is provided at the expense of the state budget of the Republic of Uzbekistan", is an example of our state's concern for the younger generation. The measures taken in decrees and resolutions will significantly reduce the number of orphanages and children deprived of parental care. Mechanisms of state support for orphans are being improved, ample opportunities have been created for their social adaptation, for the upbringing of a physically healthy and spiritually developed generation and their preparation for social family life.

The organization of such noble deeds in orphanages serves the full development of pupils. Therefore, the children of the House of Mercy are proud of their homeland, people, government and the president's care. It is these feelings of pride that inspire pupils to love their homeland and family life.

Special attention in the world is paid to preparing orphans for family life, in particular, the development of their ability to communicate with others, the ability to study and work, as well as to self-improvement and organization of their adaptation to a healthy lifestyle [4, 69]. 
In particular, it is of paramount importance to develop universal models for improving the pedagogical system of preparing children in orphanages for family life. In particular, the experience of foreign countries, such as the British system of child protection "Foster child", the American Society for the Development of Children (joint planning), the Japanese sponsorship system "Orphans Train", Cambodian limited sponsorship services "Children in Families", the child protection system in Finland, the protection of the rights of orphans in the Republic of Belarus, indicates that at present there is a need to improve the model of the pedagogical system of preparing orphans for family life [1, 53].

Today, the social adaptation of orphans and their preparation for family life is one of the most important tasks of the state and society. Particular attention should be paid to improving the pedagogical system of interaction between state and social institutions, increasing the professional competence of social workers, modernizing the education system in institutions intended for orphans and children left without parental care, in order to prepare them for family life.

In our country, in accordance with the UN Millennium Development Goals (MDGs) and the implementation of children's rights, special attention is paid to improving the system of training orphans and children left without parental care for family life, the use of innovative educational technologies based on national and world experience.

At the same time, the widespread introduction of personality-oriented educational technologies in orphanages, the strengthening of the institution of the family, the development of a preventive system for the prevention of social orphanhood, foster care, as well as the improvement of pedagogical conditions for preparing children for an independent life are of great importance. The Strategy of Actions for the Further Development of the Republic of Uzbekistan defines such important tasks as "protecting the rights of orphans and children left without parental care, increasing social activity, improving housing conditions". This shows that there is an urgent need to improve the pedagogical mechanisms for preparing children from orphanages for family life, the development of a facilitation system for pedagogical support for orphans and children left without parental care.

The main task of orphanages is the socialization of pupils. Their socialization and preparation for family life is ensured only when the educational work is carried out in concert, in mutual coordination. For this, it is advisable to organize events that reflect educational and family relationships in their own way. In the process of such educational activities, pupils must learn to take care of adults and little ones; be in a respectful relationship with adults; be able to respect parents; be in a sincere relationship with parents and older family members; they must be able to master such qualities as mutual understanding.

A peculiar pedagogical characteristic in preparing children in an orphanage for family life is also the formation of healthy lifestyle habits and adherence to certain of its rules. It is necessary to purposefully approach the organization of pedagogical activities aimed at achieving this goal. Based on the above, the following is recommended: 
- Take into account the sustainability of the stages of improving the pedagogical system of training children of the orphanage for family life (motivationalemotional, cognitive, active-value), as well as indicators of the effectiveness of the structural foundations of social, volitional and emotional (initiative and support for independent activity);

- Improving the organizational and pedagogical conditions for improving the pedagogical system of preparing orphans for family life on the basis of the organic relationship of vertical and horizontal integration of reflexive factors (scientific and pedagogical, didactic, technological, diagnostic and methodological) with methodological competence [3, 82];

- The formation of a formal dynamic structure of social adaptation to individual family life, criteria for assessing the system of preparing pupils for family life (basic, basic, productive); qualitative analysis of the results of educational activities;

- Improving the organizational and pedagogical conditions of the pedagogical system of preparing orphans for family life;

- Improvement of information and methodological support for the preparation of pupils from orphanages for family life;

- To determine the criteria and indicators for assessing the level of improvement of the pedagogical system of preparing orphans for family life, to develop scientific and methodological recommendations aimed at increasing the efficiency of this process.
Summing up, we can say that at any time and under any circumstances it is necessary to strengthen the health of orphans and children left without parental care, educate them in accordance with the requirements of the time, formwork skills in their minds, create conditions for their physical development, improving the system of preparation for family life will create ample opportunities for the pupils of the orphanage to grow up as harmonious personalities and find their place in life.

\section{ACKNOWLEDGEMENTS}

Authors acknowledge the immense help received from the scholars whose articles are cited and included in references to this manuscript. The authors are also grateful to authors/ editors/publishers of all those articles, journals and books from where the literature for this article has been reviewed and discussed.

\section{REFERENCES}

1. Dubrovina, I. V., Ruzskaya, A. G., Lisina, M. I., Avdeeva, N. N., Galiguzova, L. N., Guskova, T. V., ... \& Repina, T. A. (1990). Mental development of children in an orphanage.

2. Khaydarov I. (1996). Individual and socio-psychological features of the personality of the pupils of the houses of mercy, Abstract of the dissertation of the Candidate of pedagogical Sciences. Tashkent.

3. Egamberdieva N. (2009). Social pedagogy. Textbook for universities. Tashkent: Publishing house of the National library of Uzbekistan named after Alisher Navoi.

\section{CONCLUSION}


4. Askarova O. (2010). The system of preparation of children-orphans in public life. Toshkent, Fan.

5. Narzullaevna, H. Sh. (2020). Mehribonlik uyi tarbijalanuvchilarini oilaviy hayotga tayyorlashning pedagogik asoslari. [Pedagogical bases of preparation of the educators of the orphanage for family life]. Scientific progress, 1(1). pp.149-154. [In Uzbek].

6. Sanaeva, S. B. (2019). Preschool education instructions principles and innovative technologies of educational processing. Scientific Bulletin of Namangan State University, 1(8), 339344.

7. Pirimovna, E. G. (2020). Innovative exemplary abilities of Amir Temur in the organizational abilities of youth formation. European Scholar Journal. 1(4). pp.12-14.

8. Jabborova, D. (2019). Object and subject of educational technology. European Journal of Research and Reflection in Educational Sciences Vol, 7(12).

9. Utamurodova, Sh. М. (2020). Взгляд на историю театрального искусства. [A look at the history of theater art]. In Colloquium-journal (No. 12-3, pp. 5254). Golopristans'kij mis'krajonnij centr zajnjatosti $=$ Golopristanskij rajonnyj centr zanjatosti. [In Russian].

10. Davlatova, R. H. (2020). Studies functional-semantic field of deixis in the Uzbek language. Scientific Bulletin of Namangan State University, 2(3), 404-409.

11. Davlatova, R. H. (2019). Матн дейксиси ва унинг ўзбек тилида ифодаланиши. [Text diction and its expression in the Uzbek language]. Sostojanie, perspektivy, novye paradigmy issledovanij, 49. [In Uzbek] 